\title{
AMANTADINE HYDROCHLORIDE: INHIBITOR OF CLEAVAGE AND DNA SYNTHESIS IN SEA URCHIN OVA
}

\author{
PIERRE SOUPART,* ROBERT A. RINALDI $\$$ \\ AND VIRGINIA M. PICKEL† \\ * Department of Obstetrics and Gynecology and $\dagger$ Department of Anatomy, \\ Vanderbilt University School of Medicine, Nashville, Tennessee 37203, U.S.A.
}

(Received 19th May 1969)

Amantadine hydrochloride (Symmetrel, E. I. Du Pont de Nemours and Co.), prevents entry of some influenza viruses into host cells (Hoffmann, Newmayer, Haff \& Goldsby, 1965). Since sperm penetration into mammalian ova may be accomplished by mechanisms similar to those of virus penetration (Soupart \& Noyes, 1964; Soupart \& Clewe, 1965), we have investigated the effects of amantadine on a model fertilization system, the egg of the sea urchin, Arbacia punctulata. In these ova, a fertilization membrane is observed within $2 \mathrm{~min}$ after mixing spermatozoa and eggs, syngamy and first cleavage are completed within 15 and $70 \mathrm{~min}$, respectively, at $23^{\circ} \mathrm{C}$ and $\mathrm{pH} 8.2$ in artificial sea water (Harvey, 1956).

Gametes were collected by electrical stimulation, and the jelly coat of eggs was removed with $\mathrm{HCl}$ (Harvey, 1956). The reactivity of ova to increasing concentrations of amantadine was measured by determining the percentage of ova with fertilization membrane and the percentage of ova cleaving (on 100 ova samples). The $\mathrm{pH}$ of amantadine solutions in artificial sea water was adjusted to 8.2 by addition of anhydrous sodium carbonate. Ova from several females, exhibiting more than $90 \%$ fertilization in preliminary tests, were pooled and treated as follows: (1) fertilized and incubated in the presence of amantadine; (2) incubated for $10 \mathrm{~min}$ with amantadine, then washed three times with fresh sea water before fertilization; (3) incubated with amantadine $10 \mathrm{~min}$ after fertilization; (4) incubated with amantadine after parthenogenetic stimulation by hypertonic shock for 17 to $21 \mathrm{~min}$ (Harvey, 1956).

When fertilization occurred in presence of amantadine, the first cleavage was inhibited as a function of concentration (Table 1 ). Fifty per cent inhibition of cleavage was obtained for concentrations ranging from 25 to $50 \mu \mathrm{g} / \mathrm{ml}$, and almost total inhibition was observed for concentrations of $200 \mu \mathrm{g} / \mathrm{ml}$ and higher. Percentages of fertilization membrane formation were, in all cases, slightly higher than those for cleavage. Transfer of fertilized ova to sea water containing amantadine inhibited cleavage in the same concentration range. Fertilization membrane formation and subsequent cleavage were also inhibited in ova in-

$\ddagger$ Present address: Department of Anatomy, Georgetown University School of Medicine, Washington, D.C., 20007. 
cubated $10 \mathrm{~min}$ with amantadine and washed three times before fertilization. Cleavage following parthenogenetic activation was inhibited by amantadine in the manner described for fertilized ova. At concentrations inhibiting more than $50 \%$ cleavage, amantadine induces chemical changes in echinochrome as evidenced by a shift from bright orange to dull brown and clumping of pigment granules. At these concentrations, the fertilization membranes that still formed were irregular, eccentric or incompletely surrounded the ova. Sperm motility and fertilizing ability were not significantly altered by amantadine treatment at any concentration tested.

TABLE 1

EFFEGTS OF AMANTADINE HYDROGHLORIDE (A-HGL) ON THE GLEAVAGE OF THE EGG OF ARBAGIA PUNCTULATA

\begin{tabular}{|c|c|c|c|c|c|}
\hline & & \multicolumn{4}{|c|}{ Mean $\%$ of cleavage (and S.E.) } \\
\hline \multicolumn{2}{|c|}{$\begin{array}{r}\text { Amantadine } \\
\text { hydrochloride } \\
(\mu \mathrm{g} / \mathrm{ml}) \quad(M)\end{array}$} & $\begin{array}{c}\text { Fertilization and } \\
\text { incubation in } A-H C l \\
\quad(14 \text { expts })\end{array}$ & $\begin{array}{c}\text { Incubation in } \mathrm{A}-\mathrm{HCl} \\
10 \text { min after } \\
\text { fertilization } \\
(4 \text { expts })\end{array}$ & $\begin{array}{l}\text { Incubation } 10 \text { min } \\
\text { in } A-H C l, \text { wash, } \\
\text { fertilization } \\
(11 \text { expts })\end{array}$ & $\begin{array}{c}\text { Parthenogenetic } \\
\text { stimulation, wash, } \\
\text { incubation in } A-H C \\
(6 \text { expts })\end{array}$ \\
\hline $\begin{array}{r}10 \\
25 \\
50 \\
75 \\
100 \\
200 \\
300 \\
400 \\
500\end{array}$ & $\begin{array}{l}0.53 \times 10^{-4} \\
1.32 \times 10^{-4} \\
2.65 \times 10^{-4} \\
3.98 \times 10^{-4} \\
6.3 \times 10^{-4} \\
1.25 \times 10^{-3} \\
1.89 \times 10^{-3} \\
2.52 \times 10^{-3} \\
3.15 \times 10^{-3}\end{array}$ & $\begin{array}{rr}77 & (6 \cdot 40) \\
54 & (12 \cdot 91) \\
47 & (8 \cdot 14) \\
27 & (9 \cdot 10) \\
26 & (7 \cdot 32) \\
5 & (2 \cdot 74) \\
0 & \\
0 & \\
0 & \end{array}$ & $\begin{array}{rr}88 & (7.02) \\
83 & (11.87) \\
72 & (22.82) \\
& - \\
60 & (17.33) \\
18 & (3.65) \\
2 & (1.44) \\
0 & \\
0 & \end{array}$ & $\begin{array}{rr}91 & (9 \cdot 03) \\
88 & (12 \cdot 70) \\
66 & (10 \cdot 55) \\
39 & (21 \cdot 73) \\
20 & (7 \cdot 41) \\
15 & (7 \cdot 20) \\
4 & (2 \cdot 77) \\
4 & (2 \cdot 18) \\
1 \cdot 5(1 \cdot 31)\end{array}$ & $\begin{array}{rr}90 & (4 \cdot 38) \\
69 & (14 \cdot 82) \\
57 & (14 \cdot 63) \\
36 & (9 \cdot 36) \\
30 & (8 \cdot 21) \\
27 & (7 \cdot 83) \\
9 & (4 \cdot 31) \\
4 & (1 \cdot 48) \\
0 & \end{array}$ \\
\hline \multicolumn{2}{|c|}{ Controls } & $96(1.44)$ & $99(0.71)$ & $93(2 \cdot 22)$ & $87 \quad(5 \cdot 86)$ \\
\hline
\end{tabular}

Amantadine seems to attach firmly to some egg structure(s) or immediately causes irreversible damage, since its action was not reversed by extensive washing before fertilization. The drug acts at least on two different mechanisms: fertilization membrane formation and cleavage. This is indicated by: (1) inhibition of both fertilization membrane formation and cleavage in eggs treated with this drug before activation; (2) inhibition of cleavage following amantadine treatment of eggs in which activation was triggered either by spermatozoa or parthenogenetic stimulation. Inhibition of cleavage suggested that the effects of amantadine are comparable to those of a mitotic blocking agent such as colchicine. In a series of six experiments, the mean percentage (S.E.) cleavage in the presence of colchicine was as follows: $93(3.29), 90(3.87), 9 \cdot 2$ $(3.81), 0.2(0.05), 0 \%$ for concentrations of $5.0 \times 10^{-5}, 7.5 \times 10^{-5}, 1.0 \times 10^{-4}$, $2.5 \times 10^{-4}$ and $5.0 \times 10^{-4} \mathrm{M}$, respectively. No colour change in echinochrome was observed in presence of colchicine. With amantadine, $50 \%$ cleavage inhibition was obtained for a concentration of about $2.65 \times 10^{-4} \mathrm{M}$; whereas with colchicine, the same degree of inhibition was obtained at about $1.75 \times 10^{-4} \mathrm{M}$ as deduced from the data. When cleavage inhibition curves for colchicine and amantadine were compared, it was found that the effect of amantadine was gradual whereas that of colchicine was sudden. Colchicine blocks cleavage 

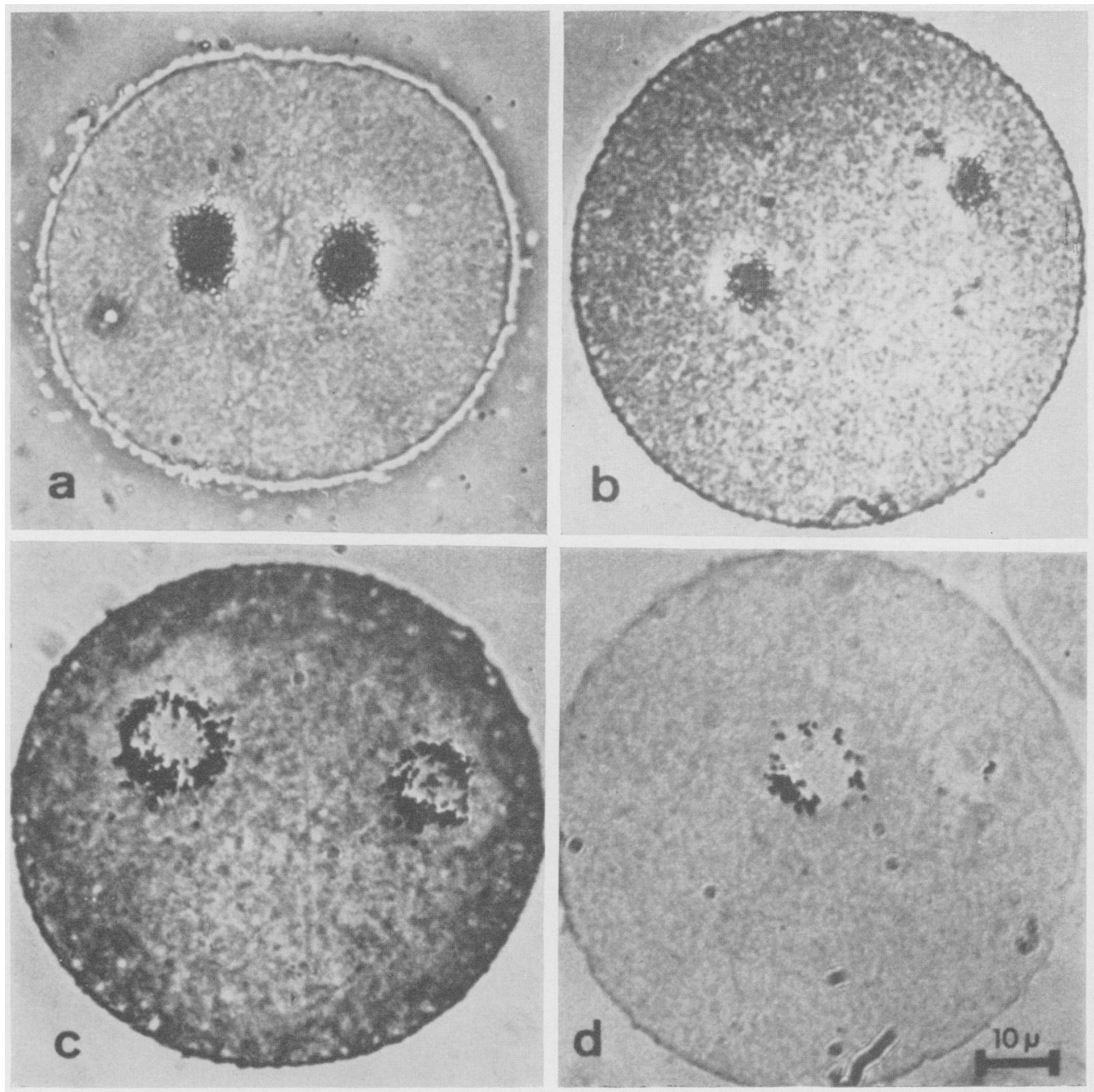

Representative autoradiographs of fertilized ova sampled after $2 \mathrm{hr}$ continuous incubation in $\left[{ }^{3} \mathrm{H}\right]$ thymidine.

Fig. 1(a). No drug treatment, two-cell stage, active DNA synthesis in nuclei.

FIc. 1(b). Colchicine $\left(1 \cdot 0 \times 10^{-3} \mathrm{M}\right)$, cleavage block, active $\mathrm{DN} A$ synthesis in pronuclei. FIG. 1(c). Amantadine hydrochloride $(100 \mu \mathrm{g} / \mathrm{ml})$, two-cell stage, depressed DN $\triangle$ synthesis in nuclear centre.

Fig. 1(d). Amantadine hydrochloride $(300 \mu \mathrm{g} / \mathrm{ml})$, cleavage block, strongly inhibited I)NA synthesis in pronuclear centre and periphery. 
by disruption of the spindle proteins of the mitotic apparatus (Inoue \& Sato, 1967) but does not affect DNA synthesis (Zimmerman \& Zimmerman, 1967).

In a further comparison of the effects of amantadine and colchicine, DNA synthesis was evaluated by autoradiography. Ova were continuously incubated with $\left[{ }^{3} \mathrm{H}\right]$ thymidine $(2.0 \mu \mathrm{c} / \mathrm{ml}$, specific activity $6.7 \mathrm{c} / \mathrm{m}$-mole $)$ in the presence of amantadine or colchicine, beginning $10 \mathrm{~min}$ before fertilization. Ova were sampled $2 \mathrm{hr}$ following fertilization, fixed in Bouin's solution, dehydrated, embedded in Araldite, and sectioned at $2 \mu$. The sections were washed in cold $5 \%$ trichloracetic acid, thoroughly rinsed in water, coated with Kodak's NTB2 emulsion, exposed for 28 days at $10^{\circ} \mathrm{G}$ and stained with thionine. Ova fertilized in the absence of amantadine or colchicine exhibited normal DNA synthesis and cleavage (Pl. 1, Fig. 1a). Although colchicine-treated ova $\left(1.0 \times 10^{-3} \mathrm{M}\right)$ did not cleave, there was active DNA synthesis in the pronuclei (Pl. 1, Fig. 1b). In amantadine-treated ova $\left(6.3 \times 10^{-4} \mathrm{M}\right)$, there was an inhibition of cleavage and a decrease in DNA synthesis in both non-cleaving and cleaving ova (Pl. 1, Fig. 1c). At higher concentrations $\left(1.9\right.$ to $3.1 \times 10^{-3} \mathrm{M}$ ), there was an arrest of cleavage with a striking inhibition of DNA synthesis (Pl. 1, Fig. 1d). The inhibition of DNA synthesis was characterized by the tracer being localized at the periphery of the nucleus and not within its central portion. This may indicate that DNA synthesis in sea urchin eggs is initiated at the nuclear membrane as recently shown for human heteroploid amnion cells (Comings \& Kakefuda, 1967). Amantadine inhibition could be achieved therefore by considerably retarding DNA synthesis.

The original purpose of our investigation was to test the effects of amantadine on sperm penetration into sea urchin ova. The data did not indicate a block to sperm penetration but revealed a definite antizygote effect in this model fertilization system.

This work was supported in part by Program Project Grant (P-HD-00673) and Training Grant (HD-00090) from the National Institutes of Health, and by research grants from the Ford Foundation and Tennessee Heart Association.

\section{REFERENCES}

Comings, D. E. \& KAKEFudA, T. (1967) Initiation of DNA replication at the nuclear membrane in human cells. (Abstracts). Annual Meeting, American Society of Human Genetics, Toronto, p. 46.

Harvey, E. B. (1956) The American Arbacia and other sea urchins. Princeton University Press.

Hofpman, C. E., Newmayer, E. M., Haff, R. F. \& Goldsby, R. A. (1965) Mode of action of the antiviral activity of amantadine in tissue culture. F. Bact. 90, 623.

Inoue, S. \& Sato, H. (1967) The contractile process. New York Heart Association. Little, Brown, Boston. Soupart, P. \& Glewe, T. H. (1965) Sperm penetration of rabbit zona pellucida inhibited by treatment of ova with neuraminidase. Fert. Steril. 16, 677.

Soupart, P. \& Noyes, R. W. (1964) Sialic acid as a component of the zona pellucida of the mammalian ovum. F. Reprod. Fert. 8, 251.

Zimmerman, A. M. \& Zimmerman, S. (1967) Action of colcemid in sea urchin eggs. J. Cell Biol. 34, 483. 